\title{
HETEROSIS AND COMBINING ABILITY IN WATERMELON HYBRIDS
}

Omran, S. A. ${ }^{1}$; W. A. E. Ramadan ${ }^{2}$ and Y. A. M. Mostafa ${ }^{3}$

1 .Veget.Breeding Dept., Horticulture Research Institute, Agriculture Research Center, Giza, Egypt

2 Veget..Self Pollinated. Res. Dept., Horticulture Research Institute, Agriculture Research Center, Giza, Egypt

3 .Veget. Cross Pollinated Res. Dept., Horticulture Research Institute, Agriculture Research Center, Giza, Egypt

\begin{abstract}
This study was carried out to produce promising hybrids of watermelon. Five lines i.e. Line $1=\mathrm{L} 84$; Line $2=\mathrm{L} 85 ;$ Line $3=\mathrm{L} 94$; Line $4=\mathrm{L} 84 \mathrm{~g}$ and Line $5=\mathrm{L}$ 63 were used as female parents and crossed with four cultivars i.e. Tester $6=$ Crimson sweet, Tester $7=$ Charleston Gray, Tester $8=$ Sugar Baby , and Tester $9=$ Giza1 as male parents (testers) using a factorial mating design ,in the summer season of 2010.Twenty hybrids and their nine parents (five lines and four testers) were evaluated at the Sakha farm of Horticulture Research Institute in the summer season of 2011 along with check variety Aswan $F_{1}$ to study heterosis and combining ability. Vine length; No. of branches per plant; No of fruits per plant; average of fruit weight; total yield per plant; No. of days to maturity and total soluble solids content ( TSS) were studied. Averages of heterosis values over better parent were positively significant for many studied traits. Both general and specific combining ability were highly significant for many traits. Line 5 is a good combiner for vine length with value 15.73 and Line 1 is a good combiner for No. of branches per plant with value of 0.88 . Line 2 is a good combiner for No. of fruit per plant with value of 0.46 . Line 3 is a good combiner for average of fruit weight and total yield per plant with values of 0.41 and1.43,respectively .. Line 2 and tester 8 were a good combiner for earliness with of values of -4 and -5.3 , respectively, and Line 4 is a good combiner for TSS\% with value of 1.19 . The best crosses were, $5 \times 6$ for vine length with value of $39.67,4 \times 8$ for No. of branches with value of $1.14,3 \times 7$ for No. of fruit per plant with value of 1.1 and $2 \times 8$ for average of fruit weight, total fruit yield per plant and TSS with values 1.7, 10.07and 1.13,respectively, $2 \times 9$ for earliness with value of -9.67

Keywords : Watermelon (Citrullus lanatus), heterosis, and combining ability.
\end{abstract}

\section{INTRODUCTION}

Watermelon [Citrulus lanatus (Thumb.) Matsum and Nakai] is one of the most important economic species of the family Cucurbitaceae. It is grown worldwide.

Mohr (1986) reported that high yield is a major goal for watermelon breeders.

The mating design (Line $x$ Tester) suggested by Kempthorne (1957) has been extensively used to estimate GCA and SCA genetic variances and their effects. Also, it is used in understanding the nature of gene action involved in the expression of economically important quantitative traits. GCA and SCA estimates, which are useful in devising breeding strategies, were reported in some cucurbits.

Today, watermelon breeders are less interested in studying heterosis, general (GCA) and specific (SCA) combining abilities, but they are 
interested in the biological protection provided by hybrid cultivars (Gusmini and Wehner, 2005). Souza et a.,I (2002) and Gvozdanovic Varga et a.,I (2011) G.observed significant GCA and SCA for the crosses and thier reciprocals and recorded higher GCA than SCA effects as well as strong additive effects for yield component trandits,. Verma et al., (2000) , Gusmini and Wehner (2005) and Soliman et al., (2008) found significant differences among parents and their $\mathrm{F}_{1}$ hybrids for GCA and SCA using the line $x$ tester mating design. Nath and Dutta (1970) mentioned that some hybrid combinations showed over $50 \%$ heterosis for yield and fruit quality. Kale and Seshadri (1988) detected heterosis for yield and fruit quality related traits in some crosses of Indian with exotic cultivars.

The main objective of this study was to determine the heterosis general and specific (GCA, SCA) and combining ability effects in watermelon hybrids.

\section{MATERIALS AND METHODS}

\section{Genetic materials}

The genetic materials used in the present study included five lines i.e. ( Line $1=\mathrm{L} 84$; Line $2=\mathrm{L} 85$; Line $3=\mathrm{L} 94$; Line $4=\mathrm{L} 84 \mathrm{~g}$ and Line $5=\mathrm{L}$ 63 )were used as female parents and crossed with four cultivars as testers i.e. $\quad$ (Tester $6=$ Crimson sweet ; Tester $7=$ Charleston Gray; Tester $8=$ Sugar Baby, and Tester $9=$ Giza1 )as male parents using a factorial mating design. All possible crosses were executed in a factorial mating design in the summer season of 2010 to produce seeds of $20 F_{1}$ crosses.

\section{Experimental design}

The experimental design used was a Randomized Complete Block Design (R.C.B.D) with three replications. Each replication or block contained 30 plots [9 parents (four testers and five lines), $20 \mathrm{~F}_{1}$ hybrids and one check cultivar ( Aswan $F_{1}$ as a check hybrid) ]. Each plot was one ridge, having 10 $\mathrm{m}$ length and $2.5 \mathrm{~m}$ width, thus making an area of $25 \mathrm{~m}^{2}$. The seeds were sown on March 15 2011 at the Sakha farm of Horticulture Research Institute, ARC. Routine cultural practices were done as needed similar to those used in watermelon production .

\section{Data recorded:}

The following characters were recorded on five plants in each plot: 1- Vine length $(\mathrm{cm}), 2-$ No. Of branches per plant, 3- No. of fruits per plant, 4Average of fruit weight $(\mathrm{kg}), 5$ - Total yield /plant kg), 6- Earliness (No. of days to maturity), and 7- Total soluble solids (TSS) ${ }^{\circ}$ Brix with a hand refractometer).

\subsection{Statistical analysis}

A regular analysis of variance of a Complete Randomized Block Design was conducted. LSD was used for the comparison between all genotypes 
means. Line $x$ tester analysis was done to provide the information about general and specific combining ability effects (Kempthorne 1957).

\section{Estimates of heterosis:}

The amount of heterosis was expressed as the percentage deviation of $F_{1}$ mean performance from better parent (BP\%) average values as follows:

$$
\text { Heterosis over better parent (\%) }=\frac{\overline{\mathrm{F}_{1}}-\overline{\mathrm{B}} \overline{\mathrm{P}}}{\overline{\mathrm{B}} \overline{\mathrm{P}}} \times 100
$$

Appropriate L.S.D. values were calculated to test the significance of these heterotic effects according to the following formulae:

L.S.D. for better parent heterosis

$$
\left(\overline{\mathrm{F}}_{1}-\overline{\mathrm{B}} \overline{\mathrm{P}}\right)=\sqrt[\mathrm{t}]{\frac{2 \mathrm{Ms}_{\mathrm{e}}}{\mathrm{r}} \times \mathrm{t}_{0.05} \text { and } \mathrm{t}_{0.01}}
$$

Where:

$M s_{e}$ : The mean squares of experimental error from the analysis of variance.

$r$ : The No. of replications.

\section{RESULTS AND DISCUSSION}

\section{Performance of parents and their $F_{1}$ hybrids :}

The results of the analysis of variance are presented in Table 1. The results indicated that the genotypes showed considerable variatin for all studied traits, indicating the presence of adequate genetic variation. The cross $5 \times 6$ had the tallest vine length with the mean value of $286.7 \mathrm{~cm}$ and the cross $3 \times 6$ had high No. Of branches per plant with the mean value of 7.1 , while line 3 had the shortest vine length $(125 \mathrm{~cm})$ and testers 8 and 9 had the lowest No. of branches per plant (3.7 and 3.7, respectively). The cross $3 \times 7$ had the highest No. Of fruits per plant (5.7). Data presented in Table 1 showed that the crosses $5 \times 7$ and $3 \times 9$ produced the highest average of fruit weight the. And two crosses $4 \times 7$ and $2 \times 8$ produced the highest total yield with the mean values of 37.5 and $37.3 \mathrm{~kg}$, respectively.

Generally, $F_{1}$ plants had higher vine length, No. of branches, No. of fruits per plant, average of fruit weight and total fruit yield per plant than their parents. Line 4 and the two crosses $2 \times 8$ and $2 \times 9$ had the lowest No. of days to maturity. Data presented in Table1 showed that the tester 6 had the highest mean value for TSS (11.7\%) 
Omran, S. A. et al.

Table 1. Mean performance of parental lines, testers, their $20 F_{1}$ and check variety for various characters in watermelon.

\begin{tabular}{|c|c|c|c|c|c|c|c|}
\hline Genotypes & $\begin{array}{c}\text { Vine } \\
\text { length }\end{array}$ & $\begin{array}{c}\text { No. of } \\
\text { branches/ } \\
\text { plant }\end{array}$ & $\begin{array}{l}\text { No. of } \\
\text { fruits/ } \\
\text { plant }\end{array}$ & $\begin{array}{c}\text { Average } \\
\text { of fruit } \\
\text { weight } \\
\text { (kg) }\end{array}$ & $\begin{array}{c}\text { Total } \\
\text { yield } \\
\text { /plant } \\
(\mathbf{k g})\end{array}$ & $\begin{array}{l}\text { No. of } \\
\text { days to } \\
\text { maturity } \\
\text { (day) }\end{array}$ & TSS \% \\
\hline \multicolumn{8}{|l|}{ Lines } \\
\hline 1 & 158.3 & 5.3 & 3.7 & 5.0 & 18.5 & 73.0 & 10.7 \\
\hline 2 & 141.6 & 5.0 & 3.3 & 4.0 & 13.2 & 71.0 & 11.3 \\
\hline 3 & 125 & 4.7 & 3.4 & 3.0 & 9.9 & 75.0 & 10.7 \\
\hline 4 & 140.0 & 3.7 & 3.0 & 4.0 & 12.0 & 68.3 & 11.3 \\
\hline 5 & 181.6 & 4.3 & 4.0 & 5.7 & 21.2 & 87.0 & 11.3 \\
\hline \multicolumn{8}{|l|}{ Testers } \\
\hline 6 & 200.0 & 4.7 & 2.0 & 6.0 & 12.6 & 88.3 & 11.7 \\
\hline 7 & 166.7 & 4.3 & 2.3 & 4.7 & 10.8 & 88.7 & 11.0 \\
\hline 8 & 138.3 & 3.7 & 4.0 & 3.3 & 13.2 & 73.0 & 11.0 \\
\hline 9 & 170.0 & 3.7 & 2.3 & 4.7 & 10.8 & 81.0 & 11.3 \\
\hline \multicolumn{8}{|l|}{ Hybrid } \\
\hline $1 \times 6$ & 205.0 & 7.0 & 4.7 & 6.3 & 21.7 & 81.7 & 10.7 \\
\hline $1 \times 7$ & 228.3 & 6.7 & 3.7 & 7.0 & 26.0 & 73.3 & 10.7 \\
\hline $1 \times 8$ & 235.0 & 5.7 & 4.3 & 6.0 & 26.0 & 71.7 & 10.0 \\
\hline $1 \times 9$ & 261.7 & 5.7 & 5.0 & 6.3 & 33.3 & 88.3 & 10.0 \\
\hline $2 \times 6$ & 230.0 & 7.0 & 4.3 & 7.0 & 30.3 & 88.3 & 10.3 \\
\hline $2 \times 7$ & 215.0 & 6.7 & 5.3 & 4.7 & 25.0 & 73.3 & 10.7 \\
\hline $2 \times 8$ & 220.0 & 5.7 & 5.3 & 7.0 & 37.3 & 69.7 & 10.7 \\
\hline $2 \times 9$ & 201.7 & 5.7 & 5.3 & 4.3 & 23.0 & 68.3 & 11.3 \\
\hline $3 \times 6$ & 213.3 & 7.1 & 4.3 & 6.3 & 27.3 & 86.7 & 11.3 \\
\hline $3 \times 7$ & 206.7 & 6.7 & 5.7 & 5.7 & 32.0 & 76.7 & 11.0 \\
\hline $3 \times 8$ & 271.7 & 5.7 & 4.1 & 7.1 & 28.7 & 81.0 & 10.3 \\
\hline $3 \times 9$ & 241.0 & 5.7 & 4.0 & 8.2 & 32.8 & 85.0 & 11.3 \\
\hline $4 \times 6$ & 221.3 & 7.0 & 5.6 & 5.3 & 29.7 & 79.3 & 10.3 \\
\hline $4 \times 7$ & 227.3 & 6.7 & 5.0 & 7.5 & 37.5 & 76.3 & 11.3 \\
\hline $4 \times 8$ & 220.0 & 5.7 & 4.1 & 5.1 & 20.6 & 75.0 & 11.3 \\
\hline $4 \times 9$ & 214.0 & 5.7 & 3.8 & 7.3 & 27.7 & 85.0 & 11.0 \\
\hline $5 \times 6$ & 286.7 & 7.0 & 4.7 & 6.3 & 29.7 & 78.3 & 11.3 \\
\hline $5 \times 7$ & 240.0 & 6.7 & 3.7 & 8.7 & 32.0 & 75.0 & 10.7 \\
\hline $5 \times 8$ & 225.0 & 5.7 & 5.0 & 4.7 & 23.3 & 70.0 & 11.0 \\
\hline $5 \times 9$ & 230.0 & 5.7 & 4.7 & 7.3 & 34.3 & 83.3 & 10.7 \\
\hline Control & 220.1 & 4.9 & 4.1 & 5.5 & 27.1 & 80.5 & 11.2 \\
\hline $\operatorname{LSD}(p=0.05)$ & 2.2 & 1.9 & 1.8 & 1.8 & 2.0 & 2.1 & 1.8 \\
\hline $\operatorname{LSD}(p=0.01)$ & 2.9 & 2.5 & 2.4 & 2.4 & 2.6 & 2.9 & 2.5 \\
\hline
\end{tabular}

*, significant at the 0.05 and 0.01 levels, respectively

\section{Heterosis}

Heterosis estimates expressed as percent increase or decrease of $F_{1}$ performance over the better parent (B.P.\%.) are presented in Table 2. Average of heterosis over better parent was highly significant with positive values for many studied traits in seedless watermelon (Soliman et al., 2008) 
Table 2. Heterosis estimates (\%) over the best parent for various traits for 20 hybrids (five lines $X$ four testers).

\begin{tabular}{|c|c|c|c|c|c|c|c|}
\hline Genotype & $\begin{array}{c}\text { Vine } \\
\text { length } \\
\text { (cm) }\end{array}$ & $\begin{array}{c}\text { No. of } \\
\text { branches/plant+ }\end{array}$ & $\begin{array}{c}\text { No. of } \\
\text { fruits/ } \\
\text { plant }\end{array}$ & $\begin{array}{c}\text { Average of } \\
\text { weight } \\
\text { fruit (kg) }\end{array}$ & $\begin{array}{c}\text { Total } \\
\text { yield } \\
\text { /plant } \\
\text { (kg) }\end{array}$ & $\begin{array}{c}\text { No. of } \\
\text { days to } \\
\text { maturity } \\
\text { (day) }\end{array}$ & TSS \% \\
\hline $\mathbf{1 X 6}$ & 2.5 & 32.1 & 26.1 & 5.6 & 17.1 & -7.5 & -13.3 \\
\hline $\mathbf{1 X 7}$ & 37.0 & 25.8 & -0.9 & 40.0 & 26.1 & -17.3 & -13.3 \\
\hline $\mathbf{1 X 8}$ & 48.5 & 6.9 & 17.1 & 20.0 & 40.5 & -1.8 & -18.7 \\
\hline $\mathbf{1 X 9}$ & 53.9 & 6.9 & 35.1 & 26.7 & 80.2 & 9.1 & -18.7 \\
\hline $\mathbf{2 X 6}$ & 15.0 & -20.0 & 31.3 & 16.7 & 129.8 & 0.0 & -18.6 \\
\hline $\mathbf{2 X 7}$ & 29.0 & 20.0 & 61.6 & -0.7 & 89.4 & -17.3 & -16.0 \\
\hline $\mathbf{2 X 8}$ & 55.4 & 0.0 & 61.6 & 75.0 & 182.8 & -8.7 & 2.4 \\
\hline $\mathbf{2 X 9}$ & 18.6 & 26.7 & 61.6 & -7.8 & 74.2 & -15.6 & -2.9 \\
\hline $\mathbf{3 X 6}$ & 6.7 & 27.7 & 27.5 & 5.6 & 116.9 & -1.8 & 2.8 \\
\hline $\mathbf{3 X 7}$ & 24.0 & -7.8 & 66.7 & 20.6 & 196.3 & -13.6 & -4.8 \\
\hline $\mathbf{3 X 8}$ & 96.4 & -0.7 & 1.7 & 114.1 & 117.2 & 9.5 & -7.3 \\
\hline $\mathbf{3 X 9}$ & 41.8 & 6.4 & 17.6 & 74.5 & 205.6 & 4.9 & -4.8 \\
\hline $\mathbf{4 X 6}$ & 10.7 & 17.1 & 86.7 & -11.7 & 150.3 & -10.2 & 16.8 \\
\hline $\mathbf{4 X 7}$ & 36.4 & 17.1 & 66.7 & 59.6 & 212.8 & -13.9 & 15.0 \\
\hline $\mathbf{4 X 8}$ & 57.1 & 64.0 & 1.7 & 26.7 & 56.3 & 2.7 & 6.6 \\
\hline $\mathbf{4 X 9}$ & 25.9 & 70.3 & 26.7 & 55.3 & 131.1 & 4.9 & 14.3 \\
\hline $\mathbf{5 X 6}$ & 43.3 & 22.0 & 16.7 & 5.6 & 39.9 & -11.3 & 8.3 \\
\hline $\mathbf{5 X 7}$ & 44.0 & 12.8 & -8.3 & 52.0 & 50.9 & -15.4 & 18.0 \\
\hline $\mathbf{5 X 8}$ & 62.7 & -19.1 & 25.0 & -18.1 & 10.1 & -19.5 & 13.4 \\
\hline $\mathbf{5 X 9}$ & 35.3 & 10.6 & 16.7 & 28.7 & 61.9 & -4.2 & -10.8 \\
\hline LSD=0.05 & 4.9 & 1.0 & 0.76 & 0.77 & 1.58 & 4.12 & 0.89 \\
\hline LSD=0.01 & 6.56 & 1.2 & 1.00 & 1.03 & 2.10 & 5.48 & 1.18 \\
\hline significant & at the 0.05 and 0.01 levels, respectively & & & & \\
\hline
\end{tabular}

All crosses had highly significant positive values of heterosis over the better-parent for vine length. Estimates of the heterosis values over better parent ranged from $2.5 \%$ in the cross $1 \times 6$ to $96.4 \%$ in the cross $3 \times 8$.The cross 4 X9 showed highly significant positive heterosis for No. of branches per plant. Most of the crosses were superior in No. of fruit per plant compared to their best parent and18 of $20 F_{1}$ hybrids showed highly significant positive estimates. The results indicated that 16 of $20 F_{1}$ hybrids showed highly significant positive estimates for average of fruit weight and ranged from 5.6to $114.1 \%$. Lippert and Legg (1972) found that heterosis estimates was significant for average weight of fruits in muskmelon. The average of heterosis estimates for total yield over the best parent were positive and highly significant for all of the studied crosses and ranged from $10.1 \%$ to $212.8 \%$ to the crosses $5 \times 8$ and $4 X 7$, respectively. Soliman et al., (2008) found significant heterosis for total yield in seedless watermelon. Nath and Dutta (1970), and Kale and Seshadri (1988) detected heterosis in watermelon for yield and fruit quality-related traits in some crosses of Indian lines with exotic cultivars. Fourteen of twenty F1 hybrids exhibited highly significant negative heterosis over better-parent for earliness (No. of days to mature). These desirable estimates ranged from $-1.8 \%$ to $-19.5 \%$. Similar results were observed by Soliman et al., (2008) in seedless watermelon. Positively highly significant values of heterosis over better parent were observed in nine $F_{1}$ 
Omran, S. A. et al.

hybrids for total soluble solids .Heterosis for total soluble solids in watermelon had been reported by and Nandpuri et al., (1974) , Banasal et al.,(2002)and Soliman et al., (2008).

\section{General and specific combining ability}

The results analysis of variance and mean squares of the factorial mating design for all traits are shown in Table (3). The results illustrated that the mean square of genotypes i.e., parents, crosses, P.vs.C, Lines, Testers and LXT were highly significant for all studied traits except for Pvc.C. for No. of days to maturity trait. These results indicate the presence of large variations among the studied genotypes and the partition of the genetic variance to its components are valid. Further, partitioning of crosses mean squares i.e. lines, testers and LXT analysis indicated that the difference due to both lines and testers were highly significant for all studied traits. The variance of crosses was partitioned into the main effect of lines and testers as the indicators of general combining ability, and interaction of line $\mathrm{x}$ testers as indicators of specific combining ability (Bond 1967).

Table 3: Analysis of variance and mean squares of factorial mating design (Line $x$ Tester) analysis for various characters in watermelon.

\begin{tabular}{|c|c|c|c|c|c|c|c|c|}
\hline S.V. & d.E & $\begin{array}{c}\text { Vine } \\
\text { length } \\
\text { (CM) }\end{array}$ & $\begin{array}{c}\text { No. of } \\
\text { branches }\end{array}$ & $\begin{array}{c}\text { No. of } \\
\text { fruits/ } \\
\text { plant }\end{array}$ & $\begin{array}{c}\text { Average } \\
\text { fruit } \\
\text { Weight } \\
\mathbf{( k g )}\end{array}$ & $\begin{array}{c}\text { Total yield } \\
\text { /plant } \\
\mathbf{( k g )}\end{array}$ & $\begin{array}{c}\text { No. of } \\
\text { days to } \\
\text { maturity } \\
\text { (day) }\end{array}$ & TSS \% \\
\hline genoyypes & 28 & 4904.14 & 2.82 & 2.76 & 6.19 & 218.07 & 143.48 & 4.29 \\
\hline Crosses(C) & 19 & 1458.157 & 2.54 & 1.22 & 4.22 & 75.72 & 131.2 & 5.61 \\
\hline Parents & 8 & 1728.704 & 1.33 & 2.17 & 3.01 & 43.13 & 190.47 & 1.63 \\
\hline P.vs.c. & 1 & 95781.32 & 20.01 & 36.72 & 68.9 & 4322.28 & 0.59 & 0.50 \\
\hline Lines & 4 & 1555.017 & 3.17 & 0.84 & 2.19 & 31.79 & 109.54 & 17.15 \\
\hline Testers & 3 & 313.8833 & 1.11 & 0.096 & 1.97 & 35.67 & 376.64 & 0.85 \\
\hline LXT & 12 & 1711.939 & 2.69 & 1.63 & 5.47 & 100.38 & 77.08 & 2.95 \\
\hline Error & 56 & 9.131773 & 0.42 & 0.21 & 0.23 & 0.93 & 6.39 & 0.30 \\
\hline
\end{tabular}

*, Sgnificant at the $\mathbf{0 . 0 5}$ and 0.01 levels, respectively.

Estimates of general combining ability effects (GCA) for individual parental lines and testers for each trait are presented in Table 4. Specific combining ability (SCA) effects for each trait are presented in Table 5. Both general and specific combining ability were highly significant for many traits in seedless watermelon (Soliman etal, 2008) 
Table 4: Estimation of general combining ability effects for various characters in parental lines and testers of watermelon.

\begin{tabular}{|c|c|c|c|c|c|c|c|}
\hline Parents & $\begin{array}{c}\text { Vine } \\
\text { length } \\
\text { (cm) }\end{array}$ & $\begin{array}{c}\text { No. of } \\
\text { branches/ } \\
\text { plant }\end{array}$ & $\begin{array}{l}\text { No. of } \\
\text { fruits } \\
\text { / plant }\end{array}$ & $\begin{array}{c}\text { Average } \\
\text { fruit weight } \\
\text { (kg) }\end{array}$ & $\begin{array}{c}\text { Total yield } \\
\text { /plant } \\
\text { (kg) }\end{array}$ & $\begin{array}{c}\text { No. of days } \\
\text { to maturity } \\
\text { (day) }\end{array}$ & TSS \% \\
\hline \multicolumn{8}{|l|}{ Lines } \\
\hline 1 & 2.82 & 0.88 & -0.21 & 0.01 & -2.73 & 0.58 & -1.81 \\
\hline 2 & -13.02 & -0.04 & 0.46 & -0.67 & 0.10 & -4.00 & $-0.5^{7}$ \\
\hline 3 & 3.48 & -0.37 & -0.11 & 0.41 & 1.43 & 4.17 & 0.69 \\
\hline 4 & -9.02 & -0.11 & -0.01 & -0.11 & 0.17 & 0.75 & 1.19 \\
\hline 5 & 15.73 & -0.36 & -0.13 & 0.35 & 1.02 & -1.5 & 0.48 \\
\hline \multicolumn{8}{|l|}{ Testers } \\
\hline 6 & 1.58 & 0.04 & 0.09 & -0.15 & -1.01 & 4.70 & 0.06 \\
\hline 7 & -6.22 & -0.04 & 0.04 & 0.30 & 1.16 & -3.23 & -0.08 \\
\hline 8 & 4.65 & -0.33 & -0.07 & -0.45 & -1.62 & -5.30 & 0.29 \\
\hline 9 & -0.02 & $0.33^{*}$ & -0.07 & 0.30 & 1.47 & 3.83 & -0.26 \\
\hline \multicolumn{8}{|l|}{ Lines } \\
\hline LSD $=0.05$ & 1.75 & 0.37 & 0.27 & 0.27 & 0.56 & 1.46 & 0.31 \\
\hline LSD $=0.01$ & 2.32 & 0.49 & 0.36 & 0.36 & 0.74 & 1.94 & 0.41 \\
\hline \multicolumn{8}{|l|}{ Testers } \\
\hline \begin{tabular}{|l|} 
LSD 0.5 \\
\end{tabular} & 1.56 & 0.33 & 0.24 & 0.25 & 0.50 & 1.30 & 0.28 \\
\hline LSD 0 & 2.08 & 0.44 & 0.32 & 033 & 0.66 & 1.73 & 0.37 \\
\hline
\end{tabular}

„, ${ }^{\star *}$ Sgnificant at the $\mathbf{0 . 0 5}$ and 0.01 levels, respectively.

Table 5. Estimation of specific combining ability affects for some various characters in the $F_{1}$ hybrids of watermelon.

\begin{tabular}{|c|c|c|c|c|c|c|c|}
\hline Crosses & $\begin{array}{c}\text { Vine length } \\
(\mathrm{cm})\end{array}$ & $\begin{array}{c}\text { No. of } \\
\text { branches/ } \\
\text { plant }\end{array}$ & $\begin{array}{l}\text { No. of } \\
\text { fruits/ } \\
\text { plant }\end{array}$ & $\begin{array}{c}\text { Average } \\
\text { of fruit } \\
\text { weight } \\
\text { (kg) }\end{array}$ & $\begin{array}{l}\text { Total } \\
\text { yield } \\
\text { /plant } \\
\text { (kg) }\end{array}$ & $\begin{array}{l}\text { No. of days } \\
\text { to maturity } \\
\text { (day) }\end{array}$ & TSS \% \\
\hline $1 \times 6$ & 29.18 & 0.71 & 0.16 & 0.06 & -3.41 & -1.78 & 0.275 \\
\hline $1 \times 7$ & 2.05 & 0.46 & -0.79 & 0.29 & -3.91 & -2.18 & 0.41 \\
\hline $1 \times 8$ & -2.15 & -0.25 & -0.02 & 0.03 & 1.54 & -1.78 & -0.63 \\
\hline $1 \times 9$ & -29.08 & -0.91 & 0.65 & -0.38 & 5.78 & 5.75 & -0.06 \\
\hline $2 \times 6$ & 11.75 & -1.377 & -0.84 & 1.40 & 2.42 & 9.47 & -1.31 \\
\hline $2 \times 7$ & 4.55 & 0.71 & 0.21 & -1.38 & -5.08 & 2.4 & -0.84 \\
\hline $2 \times 8$ & -1.32 & -0.003 & 0.32 & 1.70 & 10.07 & -2.2 & 1.13 \\
\hline $2 \times 9$ & -14.98 & 0.67 & 0.32 & -1.71 & -7.38 & -9.67 & 1.03 \\
\hline $3 \times 6$ & -20.28 & 0.96 & -0.28 & -0.34 & -1.91 & -0.37 & 0.78 \\
\hline $3 \times 7$ & -20.28 & -0.62 & 1.11 & -1.45 & 0.59 & -2.43 & -0.10 \\
\hline $3 \times 8$ & 33.85 & -0.003 & -0.38 & 0.70 & 0.04 & 3.97 & -0.79 \\
\hline $3 \times 9$ & 7.85 & -0.33 & -0.45 & 1.09 & 1.28 & -1.17 & 0.11 \\
\hline $4 \times 6$ & -0.92 & -0.97 & 0.89 & -0.85 & 2.06 & -4.28 & 0.28 \\
\hline $4 \times 7$ & 12.88 & -0.88 & 0.34 & 0.91 & 7.39 & 0.65 & -0.26 \\
\hline $4 \times 8$ & -5.32 & 1.14 & -0.48 & -0.78 & -6.73 & 1.38 & -0.63 \\
\hline $4 \times 9$ & -6.65 & 0.71 & -0.75 & 0.71 & -2.72 & 2.25 & 0.61 \\
\hline $5 \times 6$ & 39.67 & 0.69 & 0.07 & -0.27 & 0.84 & -3.03 & -0.02 \\
\hline $5 \times 7$ & 0.8 & 0.34 & -0.87 & 1.62 & 1.01 & 1.57 & 0.78 \\
\hline $5 \times 8$ & -25.07 & -0.88 & 0.57 & -1.64 & -4.88 & -1.37 & 0.92 \\
\hline $5 \times 9$ & -15.4 & -0.14 & 0.23 & 0.27 & 3.03 & 2.83 & -1.68 \\
\hline LSD $=0.05$ & 3.49 & 0.74 & 0.53 & 0.55 & 1.12 & 2.91 & 0.63 \\
\hline $\mathrm{LSD}=0.01$ & 4.64 & 0.99 & 0.70 & 0.73 & 1.48 & 3.88 & $0.8 \leq$ \\
\hline
\end{tabular}

," Significant at the $\mathbf{0 . 0 5}$ and 0.01 levels, respectively 
Data presented in Table 3 show that both GCA and SCA effects were highly significant for vine length. Results in Table 4 show that Line 5 had the greatest GCA effects followed by tester 8 . These parents could be considered as good combiners for this trait Data in Table 5 show that 7 out of 20 crosses showed significant or highly significant positive values for SCA effects for the same trait and the highest value was reflected by the crosses $5 \times 6$ and $3 \times 8$. Data in Tables 4 and 5 show that GCA and SCA for No. of branches per plant were highly significant or significant. Line 1 had the highest values of GCA effects followed by Tester 9 . Therefore, these parents were good combiners for No. of branches per plant. Estimates of SCA effects for No. of branches per plant showed that only one cross $(4 \times 8)$ out of 20 crosses showed highly significant positive value and the cross $3 \times 6$ had significant positive value, while the other crosses had negative or positive non significant values for SCA effects (Table 5). GCA and SCA for No. of fruit per plant were highly significant for few genotypes. The line 2 had the greatest GCA value and four crosses had highly significant values of SCA effects for No. of fruits per plant. The lines 3 and 5 recorded highly significant and significant values of GCA for average of fruit weight. Therefore, these parents were good combiners for this trait. The estimates of SCA effects for crosses showed that only seven crosses out of the 20 crosses had highly significant positive values of SCA effects for average of fruit weight, while the other crosses had negative or positive non-significant values. The analysis of variance for total yield per plant is presented in Tables 3 and 4 . Highly significant differences for GCA and SCA indicated that both additive and non-additive genetic variances are important in the inheritance of total yield. Data listed in Table 4 revealed that the Lines 3 and 5 and the testers 7 and 9 had the greatest GCA effect for total yield per plant. Therefore, these parents were good combiners for this trait. The estimates of SCA effects for crosses showed that seven crosses $1 \times 8,1 \times 9,2 \times 8,3 \times 9,4 \times 6,4 \times 7$ and $5 \times 9$ had positive and highly significant estimated value of SCA effects (Table 5). GCA and SCA effects for earliness (No. of days to maturity) were highly significant for most genotypes. Parent with significant negative value of GCA effects is considered as a good combiner. In contrast, the parent with positive and significant or non significant value of GCA effect are considered as late parents (poor combiners). Tester number 8,7 and line 2 possessed highly significant negative value of GCA effect. Therefore, these parents could be considered as good parents for earliness. On the other hand, the rest parents were undesired general combiners for earliness. Out of 20 crosses only 11 crosses exhibited highly significant negative values of SCA for earliness. The cross $2 \times 9$ had the highest negative estimated value of SCA effects. Analysis of variance for TSS showed highly significant differences for GCA and SCA effects. Line 3, 4, 5, and tester 8 were good combiners for TSS. Out of 20 crosses, 2 cross (2x8 and 2x9) had highly significant positive SCA effects. The diversity in GCA effects of various parents can be attributed to genetic diversity as the materials belong to diverse geographic region (Brar and Sukhija, 1977). 


\section{REFERENCES}

Bansal R, B.S. Sooch, and R.K. Dhall (2002).Heterosis in watermelon [Citrullus lanatus (Thunb.) Mansf.]. Environ Ecol .20: 976-979.

Bond, D.A. (1967). Combining ability of bean (Vicia faba L.) inbred. J. Agric. Sci. Camb. 68: 19-485

Brar, J.S. and B.S. .Sukhija (1977). Line $x$ tester analysis of combining ability in watermelon (Citrullus lanatus (Thumb.). Indian J. Hort. Sci. 34: 410414.

Gusmini G.and T.C. Wehner (2005). Foundations of yield improvement in watermelon. Crop Science 45: 141-146.

Gvozdanovic V. G.,G. M.Vasic.and G. Cervenski (2011) Diallel cross analysis for fruit traits in watermilon, Genetika,Vol.43, No 1,163-174

Kale .P.B, and V.S. Seshadri (1988). Studies on combining ability in watermelon (Citrullus lanatus (Matsumara) Nakai). Punjabrao Krishi Vidyapeeth Research J.12: 45-48

Kempthorne O .(1957). An introduction to genetic statistics. John Wiley and Sons, Inc. New York (NY, USA), $545 \mathrm{pp}$.

Lippert .L.F. and, P.D. Legg (1972). Diallel analysis for yield and maturity characteristics in muskmelon cultivars. J .Amer. Soc. Hort. Sci. 97: 8790.

Mohr H.C. (1986). Watermelon breeding. P. 37-66. In M.J. Basset (ed.). Breeding Vegetable Crops. AVI Publishing Co., Inc., Westport, USA.

Nandpuri K.S. J.C Kumar. and G.S. Dhillon (1974). Heterosis in watermelon. Punjab Hort J 14:75-83.

Nath P.,and O.P. Dutta (1970). Heterosis in watermelon. Indian J. Hortic. 27: 176-177.

Soliman A.O , T. A. Shalaby and E. M. Khalel,( 2008). Heterosis and combining ability in triploid watermelon hybrids.J.Agric.Res.Kafr-ElSkeikh Univ.34(3 )759-771.

Souza F.F; Queiroz M.A. and Dias R.C.S. (2002). Combining ability among tetraploid and iploid lines of watermelon. Hortic .Bras. 20: 654-658.

Verma T.S., R.V. Singh and, S.C. Sharma (2000). Line x Tester analysis for combining ability in cucumber. Indian J. Hort. 57: 144-147 
Omran, S. A. et al.

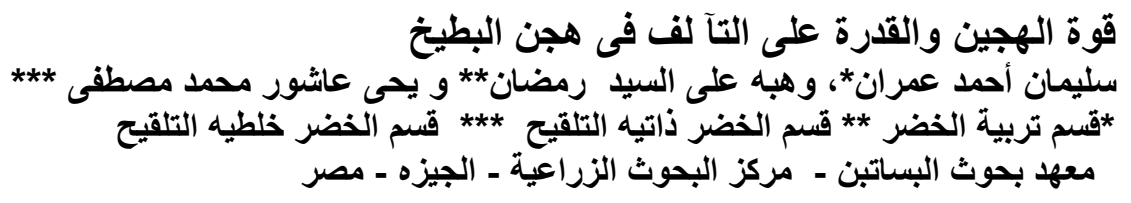

أجريت هذه الدراسة بهدف إنتاج هجن متفوقة من البطيخ ـ أستخدمت فى هذة الدراسـة

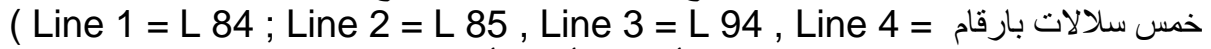
كأمهات وأربعه أصناف و وهى كرمسون سويت برقم

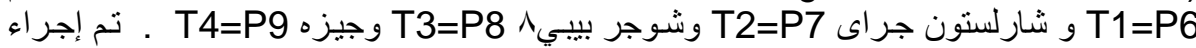

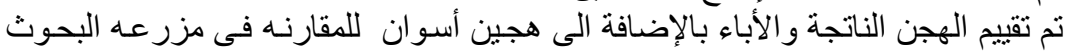

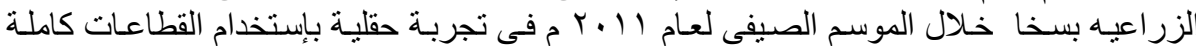

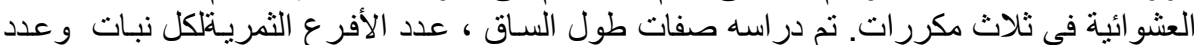

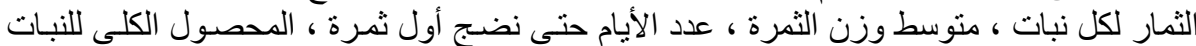
ونسبة المواد الصلبة الذائبة.

• أظهرت النتائج أن الأبـاء و الهجنة الناتجـة منها وجود فروقا معنويـة واضحة لمعظم الصفات

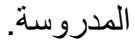

• كانت قوة الهجين عند حسـابها على أسـاس الأب الأفضل معنويـة أو عاليـة المعنويـة للعديد من

الصفات تحت الدراسة.

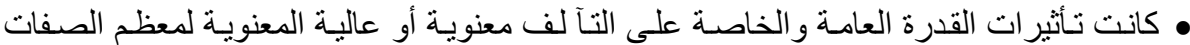

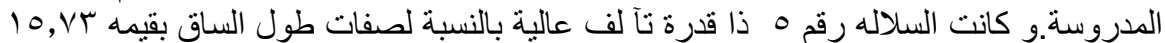

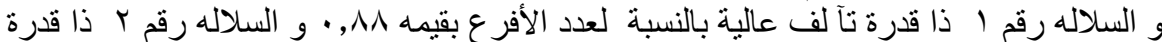

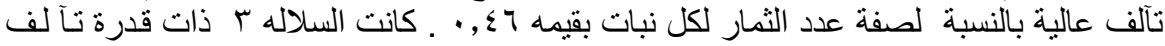

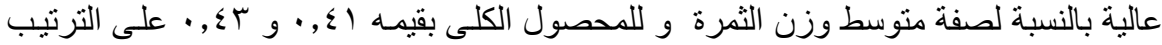

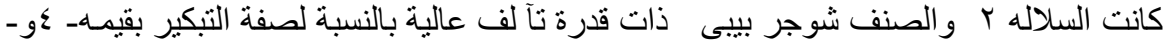

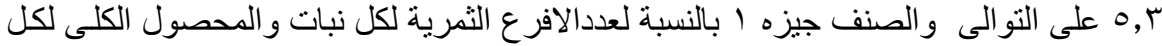

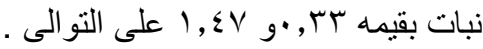

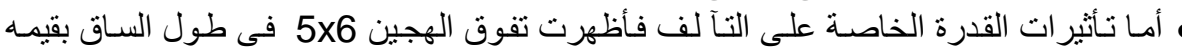

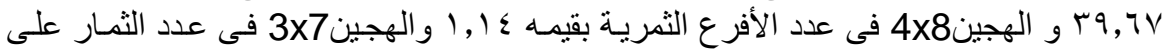

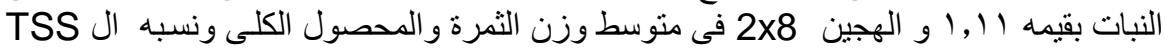

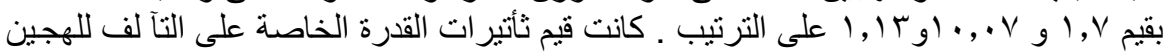

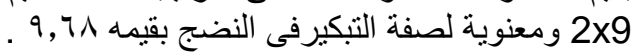

كلية الزراعة - جامعة المنصورة مركز البحوث الزراعية

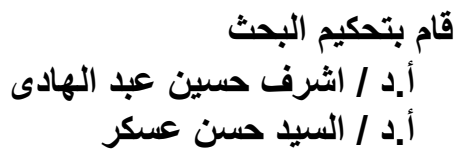

